Hilda Bernstein

Carole Collins

Stephen Lucas
Christine Messiant

Mazisi Kunene

Don Ohadike
Leonard Robinson

Philip Shea

R.J. Snow

\section{HILDA BERNSTEIN}

Johannesburg, South Africa (AP) - Hilda

Bernstein, an anti-apartheid activist and author whose husband was tried for treason alongside Nelson Mandela, has died. She was 91.

Bernstein died of heart failure at her home in Cape Town on Friday night, her son Keith said.

"The liberation movement mourns a tireless political activist whose lifelong commitment to the cause of the South African people will continue as an inspiration for generations to come," the ruling African National Congress said in a statement.

Bernstein's husband, Rusty, and Mandela were tried along with other anti-apartheid activists in the infamous Rivonia Trial in 1964. Mandela received a sentence of life imprisonment, while Rusty Bernstein was the only defendant acquitted and freed.

But police harassment made life afterward so difficult for the Bernsteins that the couple was forced into exile, leaving their children behind. They crossed the border to Botswana on foot - a journey described in Hilda Bernstein's book "The World That Was Ours."

In exile, Hilda Bernstein was an active member of the ANC and a regular speaker for the Anti-Apartheid Movement (AAM) group in Britain and abroad.

The couple eventually settled in Britain but returned to South Africa after the 1994 democratic elections that made Mandela the country's president.

Hilda Bernstein was a founding member of the Federation of South African Women, the first nonracial women's organization in South Africa. She also was a writer and artist whose work has been used as book jackets and illustrations, posters and cards for the AAM.

Bernstein was born in London in 1915 and emigrated to South Africa in 1932, working in advertising, publishing and journalism.

A fiery orator, she served as a city councilor in Johannesburg from 1943 to 1946 as the only communist elected to public office in a "whites only" vote.

She and her husband were active in the early days of the South African Communist Party and the ANC. They both suffered banning and detention by the apartheid state. Rusty Bernstein died in 2002.

Submitted by Peter Limb, Michigan State U, September 15, 2006

\section{CAROLE J. L. COLLINS}

A national leader since the 1970s in organizations seeking global economic justice, a campaigner against South African apartheid, and a writer specializing in African affairs, died at home in Long Beach, California, September 22, from complications associated with congestive heart failure. She was 59.

Collins was an anti-apartheid leader in the 1970s (with the Chicago Committee for African Liberation) and 1980s, and a crusader in the movement for Third World debt cancellation in the 1990s. After moving with her husband and son from Washington, D.C. to Long Beach in 2002, she devoted most of her energy to family.

Carole was associated with the American Friends Service Committee (AFSC) for more than
20 years. She served as AFSC's Harare, Zimbabwe-based Southern Africa International Affairs Representative in 1986-90, and traveled extensively in war-ravaged Angola and Mozambique, working with women's producer cooperatives and other community-based organizations to support grassroots reconstruction of war-ravaged communities. For most of the 16 years since her return from Africa, she has served on boards and committees responsible for supervising AFSC programs on African and global development issues.

On her first trip to Africa in 1976-77, she was a visiting lecturer on Mideast politics at Uganda's Makerere U.

In 1981-83, as national coordinator of the Campaign to Oppose Bank Loans to South Africa, she testified before city coun- 